\title{
A NEW POLYVALENT PSEUDOMONAS VACCINE
}

\author{
Jarmila M. Miler*, J. F. SPILSBURY*, R. J. Jones $\dagger$, E. A. Roe† \\ AND E. J. L. LOWBURY $\dagger$ \\ * Wellcome Research Laboratories, Langley Court, Beckenham, Kent BR3 3BS, and $\dagger$ MRC \\ Industrial Injuries and Burns Unit, Accident Hospital, Bath Row, Birmingham B15 1NA
}

PSEUDOMONAS AERUGINOSA is an opportunistic pathogen commonly associated with nosocomial infections (Lowbury, 1975), especially in debilitated patients such as those with burns (Lowbury, 1972; Jones, 1975), cystic fibrosis (Dogett and Harrison, 1972), organ malfunctions (Hill et al., 1967) and cancer (Armstrong et al., 1971). Owing to the limited capacity of antibiotics against pseudomonas infections and the tendency for resistance to emerge (Lowbury and Jones, 1975), immunological methods offer an alternative protection which is especially appropriate in combatting infections with this organism. Infection can be caused by a strain belonging to any of the 16 internationally recognised serological groups of P. aeruginosa (Bergan, 1975), and it is therefore important that a vaccine should give protection against the whole range.

In recent years, pseudomonas vaccines have been prepared from killed whole bacterial cells (Zellner, Metzger, and Zwisler, 1965; Feller, 1966), extracts of cells (Hanessian et al., 1971) and culture filtrates (Jones, 1968). In this paper a new medium for producing highly immunogenic pseudomonas vaccines and a new method for extracting the immunogens from the cell walls of each of the 16 serotypes of $P$. aeruginosa are described. The chemical composition and immunogenic properties of 16 monovalent vaccines and a combined 16-part polyvalent vaccine is reported.

\section{MATERIALS AND METHODS}

Strains of $P$. aeruginosa. Strains of $P$. aeruginosa selected for making the vaccines (16 strains) and for testing the efficacy of the vaccines in mice (150 strains) were obtained from 35 hospitals in the United Kingdom (75\%) and from India (11\%), Eire, Japan, Hungary and Romania. All strains of $P$. aeruginosa were serotyped and phage typed by Mr T. Pitt at the Central Public Health Laboratory, Colindale.

Vaccine production. Pilot experiments suggested that the most protective vaccines were made from the surface antigens of virulent strains of $P$. aeruginosa (Jones, 1969). The virulence of 150 strains of $P$. aeruginosa was tested by an intraperitoneal challenge test in mice (Jones, 1970). The first batch of vaccines was made from the most virulent strain of each of the 16 serotypes of $P$. aeruginosa. The vaccines were designated by the serotype number of the constituent strain.

Preliminary experiments indicated that by using ammonium lactate as the sole nitrogen source and a suitable concentration of trace elements the formation of toxic adaptive enzymes and pigments could be almost suppressed. Furthermore, it was shown that the relative concentration of various divalent cations influenced the liberation of immunogens into the medium during growth and that by using a suitable concentration of magnesium and calcium

Received 6 May 1976; accepted 20 May 1976.

J. MED. MICROBIOL.-VOL. 10 (1977) 
ions the immunogens were completely retained within the cell wall throughout the logarithmic phase of growth. These observations were used in the formulation of the synthetic medium described below.

Each strain of $P$. aeruginosa was grown for $16 \mathrm{~h}$ at $37^{\circ} \mathrm{C}$ in 4 litres of synthetic medium (1 litre contained: glucose $13.6 \mathrm{~g}$; ammonium lactate $60 \%(\mathrm{w} / \mathrm{w}) 13.6 \mathrm{ml} ; \mathrm{CaCl}_{2} 15 \mathrm{mg}$; $\mathrm{MgCl}_{2} 66 \mathrm{mg} ; \mathrm{NaCl} 2.92 \mathrm{~g} ; \mathrm{KH}_{2} \mathrm{PO}_{4} 1.36 \mathrm{~g} ; \mathrm{Na}_{2} \mathrm{SO}_{4} 60 \mathrm{mg}$ : $\mathrm{FeCl}_{3} 0.2 \mathrm{mg} ; \mathrm{ZnSO}_{4} .7 \mathrm{H}_{2} \mathrm{O}$ $0.18 \mathrm{mg} ; \mathrm{CuSO}_{4} .4 \mathrm{H}_{2} \mathrm{O} 0.04 \mathrm{mg} ; \mathrm{MnSO}_{4} .4 \mathrm{H}_{2} \mathrm{O} 0.02 \mathrm{mg} ; \mathrm{Na}_{2} \mathrm{MoO}_{4} .2 \mathrm{H}_{2} \mathrm{O} 0.02 \mathrm{mg}$; $\mathrm{Ga}\left(\mathrm{NO}_{3}\right)_{3} 0.02 \mathrm{mg}$ ). This medium was buffered to $\mathrm{pH} 7.5$ with Tris buffer. Cultures were agitated with a stainless-steel vortex stirrer at 1200-1500 r.p.m. and 2 litres per min. of sterilised air was passed over the vortex. Bacteria were harvested by centrifugation $(1900 \mathrm{~g}$, 1-2 $\mathrm{h}, 4^{\circ} \mathrm{C}$ ) when cultures had reached the peak of the logarithmic growth phase (normally $16 \mathrm{~h}$ ). A viable count was made by the method of Miles, Misra, and Irwin (1938).

Extraction of vaccines. Bacteria $\left(3-5 \times 10^{10}\right.$ viable bacteria per $\left.\mathrm{ml}\right)$ were shaken gently with EDTA-glycine mixture for $2 \mathrm{~min}$. at $37^{\circ} \mathrm{C}$. After centrifugation $(9000$ r.p.m., 60 min., $4^{\circ} \mathrm{C}$ ) the supernate containing the immunogen was sterilised by filtration through Seitz EKS filter pads, diluted with an equal volume of formalin $0.6 \%(\mathrm{v} / \mathrm{v})$ in distilled water and stored in sealed glass containers at $4^{\circ} \mathrm{C}$. The diluted, sterile extract constituted the vaccine; its concentration was expressed in terms of the number of viable colony-forming units (microbial equivalents) per $\mathrm{ml}$ from which it was extracted.

The polyvalent vaccine. The 16 vaccines, one from each serotype of $P$. aeruginosa were each incorporated in the polyvalent vaccine at a concentration of $1 \times 10^{8}$ microbial equivalents per $\mathrm{ml}$. The total number of microbial equivalents in the polyvalent vaccine was, therefore, $1.6 \times 10^{9}$ per $\mathrm{ml}$. The individual type vaccines were selected for the polyvalent vaccine on the basis of results of protection and toxicity tests (vide infra), because they were the most immunogenic and least toxic of the vaccines made from each serotype. The polyvalent vaccine was freeze-dried.

Chemical characterisation. Equal portions of each of the 16 vaccines and the EDTAglycine extracting medium were dialysed against 20 volumes of distilled water for $36 \mathrm{~h}$ at $4^{\circ} \mathrm{C}$. The dialysed materials were dried at $105^{\circ} \mathrm{C}$ for $48 \mathrm{~h}$ in glass containers. The following chemical determinations were made on each vaccine: total nitrogen by the Kjeldahl micromethod (Varley, 1962); protein content (Hartree, 1972); lipid content (Folch, Lees and Sloane-Stanley, 1957); carbohydrate content (Dubois et al., 1956); organic phosphorus content (Bartlett, 1959).

Chick-embryo toxicity test. Groups of 20 11-day-old white Leghorn chicken embryos were given intravenous injections of $0.1 \mathrm{ml}$ of four serial 10 -fold dilutions in pyrogen-free physiological saline of both monovalent and polyvalent vaccines. Control groups were given injections of pyrogen-free saline. Toxicity was determined by the number of survivors $24 \mathrm{~h}$ after injection (Milner and Finkelstein, 1966).

Mouse toxicity test. Groups of 10 mice (each $18-20 \mathrm{~g}$ in weight) were given intraperitoneal injections of $0.5 \mathrm{ml}$ of decreasing 10 -fold dilutions in saline $\left(1 \times 10^{10}\right.$ to $1 \times 10^{1}$ microbial equivalents per $0.5 \mathrm{ml}$ ) of each of the dialysed monovalent vaccines. Mice were observed for 7 days for any signs of abnormality. The polyvalent vaccine was tested similarly; the range of dilutions that were tested contained $1.6 \times 10^{10}$ to $10^{6}$ microbial equivalents per $0.5 \mathrm{ml}$.

Rabbit pyrogenicity test. Each of the 16 vaccines and the polyvalent vaccine were injected into groups of four rabbits (New Zealand White, 12-14 kg) in $0.5-\mathrm{ml}$ amounts containing $2 \times 10^{4}$ microbial equivalents per $0.5 \mathrm{ml}$. Four rabbits were given intradermal and four subcutaneous injections on days $0,4,7,10$ and 14 . The rectal temperature of the rabbits was recorded hourly for $5 \mathrm{~h}$ after each injection on a temperature recorder (Sienex Ltd, 15, Clipstone Road, London W1, type 2-8).

Rabbit skin test. The local skin reaction to intradermal and subcutaneous injections of polyvalent vaccine in rabbits, described above, was recorded. The area around the injection was observed for 3 days for signs of erythema, oedema, necrosis, induration and vasoconstriction.

Immunogenic properties of vaccines. A single 1-ml volume of vaccine was injected intraperitoneally into each mouse (either male Olac or Schofield mice, 18-20 g weight). A 
range of dosages of vaccine was used as shown in Results. Dilutions of the vaccine were made in physiological saline from stock solutions of the vaccines each containing $1 \times 10^{9}$ microbial equivalents per $\mathrm{ml}$.

To test the protection induced by vaccination, the mice were challenged intraperitoneally either on the 3rd or the 4th day after vaccination with $1-\mathrm{ml}$ saline suspensions of $P$. aeruginos $a$ containing 2 LD50 or 1 MLD. The details of vaccination and challenge have previously been described (Jones, 1971). The MLD of the 150 strains of $P$. aeruginosa were determined by intraperitoneal challenge (Jones, 1970). After challenge, vaccinated mice were observed for $48 \mathrm{~h}$; control groups of unvaccinated mice were included in each experiment.

TABLE I

Chemical composition of the 16 monovalent vaccines

\begin{tabular}{l|rr}
\hline \multicolumn{1}{c|}{ Components } & \multicolumn{2}{c}{$\begin{array}{c}\text { Concentrations }(\mu \mathrm{g} \text { per } \\
\text { ml) of chemical } \\
\text { components in the } \\
\text { vaccine }\end{array}$} \\
\hline & $\overbrace{\text { Mean }}$ & Range \\
\hline Total nitrogen & 18.39 & \pm 3.58 \\
Protein & 38.29 & \pm 25.65 \\
Carbohydrate & 37.92 & \pm 10.92 \\
Organic phosphorus & 2.45 & \pm 0.58 \\
Lipid & 51.66 & \pm 40.24 \\
Dry weight & 330.63 & \pm 49.52 \\
\hline
\end{tabular}

\section{RESULTS}

\section{Chemical characterisation of pseudomonas vaccine}

The main components of the 16 pseudomonas vaccines (table I) were protein and carbohydrate, each c. $13 \%$ of dry weight, and lipid, c. $20 \%$. There were considerable variations in the actual amounts of these components in the individual vaccines, but the proportions of protein and carbohydrate to lipid were relatively constant.

\section{Toxicity tests}

At the concentration at which each vaccine was incorporated into the polyvalent vaccine $\left(1 \times 10^{8}\right.$ microbial equivalents per $\left.\mathrm{ml}\right)$ none of the 16 individual vaccines nor the polyvalent vaccine, which contained a total of $1.6 \times 10^{9}$ microbial equivalents per $\mathrm{ml}$, killed mice on intraperitoneal injection and none caused a rise of temperature on injection into rabbits at $2 \times 10^{4}$ microbial equivalents per $0.5 \mathrm{ml}$. The 16 individual vaccines did not kill groups of 10 mice when injected at a higher dosage of $1 \times 10^{9}$ microbial equivalents.

The chick-embryo test showed the 16 vaccines differed widely in their toxicity for 11-day-old chick embryos. The least toxic vaccines (nos. 2, 3, 8, 9 and 11) failed to kill chick embryos infected with $0.1 \mathrm{ml}$ of the vaccines containing $3 \times 10^{8}$ microbial equivalents in $0 \cdot 1 \mathrm{ml}$. Some vaccines (nos. 4, 7, 


\section{TABLE II}

Protection of mice by vaccines extracted from 16 different serotypes of Pseudomonas aeruginosa against challenge with 1 MLD of strains of the same serotype

\begin{tabular}{c|c}
$\begin{array}{c}\text { Serotype of strains used for vaccination } \\
\text { and challenge }\end{array}$ & $\begin{array}{c}\text { Number of strains against which vaccinated } \\
\text { mice were protected }\end{array}$ \\
\hline 1 & \\
2 & $10 / 10$ \\
3 & $14 / 14$ \\
4 & $13 / 13$ \\
5 & $14 / 14$ \\
6 & $13 / 13$ \\
7 & $11 / 11$ \\
9 & $15 / 15$ \\
9 & $9 / 9$ \\
11 & $10 / 10$ \\
12 & $10 / 11$ \\
13 & $10 / 10$ \\
14 & $1 / 1$ \\
15 & $9 / 10$ \\
16 & $1 / 11$ \\
\hline
\end{tabular}

14 and 15) were 100 times more toxic for chick embryos than nos. 2, 3, 8, 9 and 11.

\section{Protective properties of pseudomonas vaccines}

Table II shows that each of the vaccines made from 16 different serotypes of $P$. aeruginosa was highly successful in inducing protection of mice against lethal challenge (1 MLD) by the strains of $P$. aeruginosa used for preparing the vaccine (autologous challenge) and by other strains of the same serotype (homologous challenge). Only one strain of each of serotypes 12, 14, 15 and 16 was available for challenge.

The vaccinated mice used in this experiment were protected against 142 of 144 strains of $P$. aeruginosa. The single strains of $P$. aeruginosa against which vaccines nos. 10 and 13 failed to give protection were of low virulence

TABLE III

Cross-protection of mice by vaccine no. 4 against challenge with strains of serotypes 4,7 and 11

\begin{tabular}{cc|cc}
\hline $\begin{array}{c}\text { Serotype } \\
\text { of } \\
\text { vaccine }\end{array}$ & $\begin{array}{c}\text { Serotype of } \\
\text { challenge strains }\end{array}$ & \multicolumn{2}{c}{$\begin{array}{c}\text { Number of strains against which } \\
\text { vacine 4 protected mice } \\
\text { immunized with vaccine dilution of }\end{array}$} \\
\cline { 3 - 3 } & & $10^{-1 *}$ & $10^{-2}$ \\
\hline 4 & 4 & $\begin{array}{c}10 / 10 \\
5 / 8\end{array}$ & $\begin{array}{c}8 / 10 \\
2 / 8 \\
0 / 5\end{array}$ \\
4 & 11 & $1 / 5$ & \\
\hline
\end{tabular}

* This dilution contained $10^{8}$ microbial equivalents in $1 \mathrm{ml}$. 
and required respectively three and six times more bacteria than average $\left(2 \times 10^{7}\right.$ per mouse $)$ to kill unvaccinated mice.

Cross-protective properties of vaccine no. 4 against strains of $\mathrm{P}$. aeruginosa from different serotypes

Table III gives an example of the cross-protective properties shown by each of the 16 pseudomonas vaccines. Vaccine no. 4 induced protection against all 10 challenge strains of serotype 4, but against only 5 of 8 and 1 of 5 challenge strains respectively of serotypes 7 and 11 . While all 16 vaccines protected mice against autologous challenge (table II) they gave protection against only some of the bacteria of heterologous serotypes. A polyvalent vaccine containing representative strains of each serotype was therefore thought to be necessary for the protection of patients against the whole range of $P$. aeruginosa strains.

Comparison of the protective properties of the polyvalent vaccine with those of the 16 monovalent vaccines

Table IV shows a comparison of the protective properties of the polyvalent vaccine with those of the 16 component monovalent vaccines, in terms of their ED50 against lethal intraperitoneal autologous challenge (i.e., with

TABLE IV

Comparison of the protective properties in mice of the 16 monovalent vaccines and the polyvalent vaccine against challenge with $P$. aeruginosa strains autologous to the monovalent vaccine

\begin{tabular}{|c|c|c|c|c|}
\hline \multirow{2}{*}{$\begin{array}{l}\text { Serotype of } \\
\text { challenge } \\
\text { strain of } \\
P . \text { aeruginosa }\end{array}$} & \multirow{2}{*}{$\begin{array}{c}\text { LD50 of } \\
\text { challenge } \\
\text { strain* } \\
\text { (colony-forming } \\
\text { units in } 1 \mathrm{ml} \text { ) }\end{array}$} & \multirow{2}{*}{$\begin{array}{c}\text { Actual } \\
\text { challenge } \\
\text { dose } \\
\text { given* } \\
\text { (colony-forming } \\
\text { units in } 1 \mathrm{ml} \text { ) }\end{array}$} & \multicolumn{2}{|c|}{$\begin{array}{l}\text { Protective properties (ED50) } \\
\text { of vaccines in mice challenged } \\
3 \text { days after one injection of }\end{array}$} \\
\hline & & & $\begin{array}{l}\text { monovalent } \\
\text { vaccine }\end{array}$ & $\begin{array}{l}\text { polyvalent } \\
\text { vaccine }\end{array}$ \\
\hline $\begin{array}{r}1 \\
2 \\
3 \\
4 \\
5 \\
6 \\
7 \\
8 \\
9 \\
10 \\
11 \\
12 \\
13 \\
14 \\
15 \\
16\end{array}$ & $\begin{array}{l}4 \cdot 6 \times 10^{7} \\
1.9 \times 10^{7} \\
3 \cdot 5 \times 10^{7} \\
7 \cdot 9 \times 10^{7} \\
2 \cdot 7 \times 10^{7} \\
8 \cdot 3 \times 10^{6} \\
1 \cdot 3 \times 10^{7} \\
2 \cdot 2 \times 10^{7} \\
2 \cdot 2 \times 10^{8} \\
2 \cdot 5 \times 10^{7} \\
2 \cdot 9 \times 10^{7} \\
1 \cdot 7 \times 10^{8} \\
1 \cdot 6 \times 10^{8} \\
1 \cdot 0 \times 10^{8} \\
4 \cdot 7 \times 10^{8} \\
8 \cdot 9 \times 10^{7}\end{array}$ & $\begin{array}{l}2.0 \times 10^{8} \\
1.0 \times 10^{8} \\
1.0 \times 10^{8} \\
3.0 \times 10^{8} \\
1.0 \times 10^{8} \\
5.0 \times 10^{7} \\
5.0 \times 10^{7} \\
9.0 \times 10^{7} \\
5.0 \times 10^{8} \\
9.0 \times 10^{7} \\
2.5 \times 10^{8} \\
5.0 \times 10^{8} \\
5.0 \times 10^{8} \\
7.0 \times 10^{8} \\
9.0 \times 10^{8} \\
3.0 \times 10^{8}\end{array}$ & $\begin{array}{l}3 \cdot 1 \times 10^{5} \\
3.3 \times 10^{3} \\
1.1 \times 10^{2} \\
4 \cdot 4 \times 10^{4} \\
1 \cdot 2 \times 10^{3} \\
2 \cdot 6 \times 10^{2} \\
5 \cdot 3 \times 10^{2} \\
5 \cdot 2 \times 10^{4} \\
2 \cdot 1 \times 10^{4} \\
1 \cdot 4 \times 10^{4} \\
1 \cdot 3 \times 10^{7} \\
1 \cdot 2 \times 10^{2} \\
3 \cdot 2 \times 10^{5} \\
7 \cdot 0 \times 10^{6} \\
3 \cdot 3 \times 10^{5} \\
8.2 \times 10^{6}\end{array}$ & $\begin{array}{l}4.8 \times 10^{4} \\
3.2 \times 10^{4} \\
6.4 \times 10^{4} \\
1.8 \times 10^{5} \\
8.0 \times 10^{4} \\
1.6 \times 10^{5} \\
6.4 \times 10^{4} \\
2.9 \times 10^{5} \\
1.9 \times 10^{5} \\
7.8 \times 10^{7} \\
1.6 \times 10^{4} \\
1.6 \times 10^{4} \\
3.2 \times 10^{4} \\
5 \cdot 1 \times 10^{5} \\
2.3 \times 10^{7} \\
2.1 \times 10^{6}\end{array}$ \\
\hline
\end{tabular}

* The LD50 of the challenge strains and the challenge doses for mice are expressed in terms of living organisms determined by a viable plate count made before challenge.

$\dagger$ The ED50 is expressed as the number of bacteria from which the immunising dose was extracted (microbial equivalents). 
bacteria from which the vaccines were made). The challenge was given 3 days after one injection of vaccine. The component vaccines showed a wide range of protective properties (ED50s ranged between $1.1 \times 10^{2}$ and $1.3 \times 10^{7}$ ), while the polyvalent vaccine showed less variation in its protective properties (ED50s against the 16 autologous challenges ranged between $1.6 \times 10^{4}$ and $7 \cdot 8 \times 10^{7}$. The polyvalent vaccine induced more protection against infective challenge than five of the component vaccines (nos. 1, 11, 13, 14 and 16); the other 11 component vaccines induced less protection of mice when combined with other vaccines in the polyvalent vaccine than when used alone.

TABLE V

Protection of mice with a polyvalent vaccine against $P$. aeruginosa

\begin{tabular}{|c|c|c|c|c|}
\hline \multirow{2}{*}{$\begin{array}{l}\text { Serotype of strains of } \\
P \text {. aeruginosa used for } \\
\text { challenge }\end{array}$} & \multicolumn{4}{|c|}{$\begin{array}{l}\text { Number of strains, of the three tested, } \\
\text { against which mice were protected by } \\
\text { polyvalent vaccine at dilutions of }\end{array}$} \\
\hline & $10^{-1 *}$ & $10^{-2}$ & $10^{-4}$ & $10^{-6}$ \\
\hline $\begin{array}{c}1 \\
2 \\
3 \\
4 \\
5 \\
6 \\
7 \\
8 \\
9 \\
10 \\
11 \\
12 \dagger \\
13 \\
14 \dagger \\
15 \dagger \\
16^{\dagger} \dagger\end{array}$ & $\begin{array}{l}3 \\
3 \\
3 \\
3 \\
3 \\
3 \\
3 \\
3 \\
3 \\
3 \\
3 \\
1 \\
3 \\
1 \\
1 \\
1\end{array}$ & $\begin{array}{l}3 \\
3 \\
3 \\
3 \\
3 \\
3 \\
2 \\
3 \\
3 \\
3 \\
3 \\
1 \\
2 \\
1 \\
1 \\
1\end{array}$ & $\begin{array}{l}1 \\
1 \\
2 \\
1 \\
1 \\
1 \\
1 \\
1 \\
1 \\
2 \\
1 \\
0 \\
0 \\
0 \\
0 \\
0\end{array}$ & $\begin{array}{l}0 \\
1 \\
0 \\
0 \\
0 \\
0 \\
0 \\
0 \\
2 \\
1 \\
0 \\
0 \\
0 \\
0 \\
0 \\
0\end{array}$ \\
\hline
\end{tabular}

Protection against strains of $\mathrm{P}$. aeruginosa of the 16 serotypes by the polyvalent vaccine

Table $\mathrm{V}$ shows that a $10^{-1}$ dilution of polyvalent vaccine induced protection in mice against 1 MLD challenges of 40 of 40 different strains of $P$. aeruginosa. The pseudomonas strains used for challenge in this experiment were the three most virulent strains of each serotype (except serotypes 12, 14, 15 and 16 of which only the autologous strains were used). At a dilution of $10^{-2}$ the polyvalent vaccine was still highly effective, inducing protection in mice against 38 of 40 strains of $P$. aeruginosa.

\section{DISCUSSION}

The most effective protection-inducing components of $P$. aeruginosa are its surface antigens (Alms and Bass, 1965; Alexander, Fisher and MacMillan, 
1970; Jones, 1971); these immunogenic antigens are also associated with factors that determine the virulence of the bacteria (Liu, Abe and Bates, 1961; Carney and Jones, 1968). The most immunogenic pseudomonas vaccines are those that are not denatured by the extraction process (Jones, 1972). Vaccines made from autolysed batch cultures of $P$. aeruginosa are highly immunogenic (Jones, 1969), but such vaccines are contaminated with culture medium, enzymes and other potentially toxic components (Jones, 1968). The new method described in this paper for extracting immunogens from $P$. aeruginosa gives a high yield of immunogens free from toxic components. The medium used for growing the bacteria was specially designed to suppress the synthesis of toxic pigments and adaptive enzymes. This was achieved by offering the bacteria compounds which were readily assimilated, e.g., ammonium lactate as the sole source of nitrogen, and by regulating the amounts of magnesium and calcium ions in the medium, so that the entire immunogenic activity of the bacteria was retained in their cell walls. The immunogens were removed from the cell wall of living bacteria in their log phase of growth by a few minutes' exposure to an EDTA-glycine mixture.

Experiments have shown that extractants containing EDTA, a chelating agent for divalent cations, will remove proteins, lipids and carbohydrates from the cell walls of gram-negative bacteria (Leive, 1968). The addition of glycine to the EDTA extractant enhanced the amount of immunogen released from the living bacteria. Glycine used without EDTA produced a high proportion of toxin as well as immunogen. Only one extraction of the immunogen was found necessary, and the extraction was so mild that the bacteria were still alive afterwards.

The 16 vaccines, one prepared from each serotype of $P$. aeruginosa, each induced an early protective response in mice. Within 3 days of a single injection of vaccine, mice were protected against 1 MLD challenge both of the autologous strain and of several other strains of $P$. aeruginosa of the same serotype. Crossprotection by the vaccines against strains of bacteria of the heterologous serotypes was variable and too uncertain and inconsistent to be used as the basis for formulation of a polyvalent vaccine. The main concern when it became apparent that a 16-part vaccine would be needed to provide protective cover against all strains of all serotypes was that on combining the vaccines there would be a substantial loss of immunogenicity, which might be reduced to less than the expected level of $1 / 16$, and that there might be antagonism between component vaccines. However, five of the vaccines (nos. 1, 11, 13, 14 and 16) when combined in the polyvalent vaccine, gave better protection against autologous challenge than when used as monovalent vaccines. With the exception of vaccines nos. 3, 6, 7, 10 and 12, which had better immunising properties when used individually than in the polyvalent mixture, the protection induced by the polyvalent vaccine was similar to that induced by the component vaccines. The polyvalent vaccine also protected mice against several strains of the 16 serotypes when diluted one-hundred fold.

The component vaccines in the polyvalent vaccine were each represented at a concentration of $1 \times 10^{8}$ microbial equivalents per $\mathrm{ml}$, a concentration 
at which the vaccines showed no toxicity for mice, rabbits or chick embryos. At this concentration $\left(1 \times 10^{8}\right.$ microbial equivalents per $\left.\mathrm{ml}\right)$ the 16 vaccines showed a variety of protective activities, e.g., vaccine no. 3 had an ED50 of $1.1 \times 10^{2}$ against autologous challenge, while vaccine 11 had an ED50 of $1.3 \times 10^{7}$. The discrepancy in the amounts of protective antigen produced from a similar number of bacteria $\left(1 \times 10^{8}\right)$ is not related to the virulence of the vaccine-producing strains of $P$. aeruginosa, because the most virulent strain (no. 6), which had an LD50 of $8.3 \times 10^{6}$ per mouse, produced a vaccine of protective potency similar to that of strain no. 12, which had an LD50 of $1.7 \times 10^{8}$ per mouse. The most potent vaccines, in terms of the amount of immunogen produced by the bacteria, seemed to be those that contained the highest ratio of protein and carbohydrate to lipid, a fact that may prove useful in future screenings of strains of $P$. aeruginosa for protective immunogens.

The new polyvalent pseudomonas vaccine has been tested in human volunteers and shown to give satisfactory protection against all serotypes (16) of $P$. aeruginosa (Jones et al., 1976). A controlled trial of the vaccine in patients with burns is planned.

\section{SUMMARY}

This paper describes the preparation, chemical characterisation and immunogenic properties of a new polyvalent pseudomonas vaccine.

New cultural methods were devised which allowed a build-up of the immunogen in the cell wall of the bacteria, and mild extraction techniques were used to remove the immunogens from the cell wall of living bacteria without apparent physical or chemical change which might affect immunogenicity.

The polyvalent vaccine comprised 16 component vaccines, each a lipidprotein-carbohydrate complex extracted from one of the 16 different serotypes of Pseudomonas aeruginosa.

Single injections into mice of each of the 16 component vaccines induced protection against several strains of homologous serotypes within 3 days of vaccination. The polyvalent vaccine induced similar protection against several strains of each of the 16 serotypes.

We would like to thank R. E. Dyster, K. Digby and J. Simmonds for their technical assistance.

\section{REFERENCES}

AleXander, J. W., Fisher, M. W. And MacMillan, B. G. 1970. Immunological control of pseudomonas infections in burn patients: a clinical evaluation. Archs. Surg., 102, 31.

Alms, T. H. AND Bass, J. A. 1965. Mouse protective antigen from Pseudomonas aeruginosa. Tex. Rep. Biol. Med., 23, 140.

Armstrong, D., Young, L. S., Meyer, R. D. And Belvins, A. H. 1971. Infectious complications of neoplastic disease. Med. Clins N. Am., 55, 729.

Bartlett, G. R. 1959. Phosphorus assay in column chromatography. J. biol. Chem., 234, 466.

Bergan, T. 1975. Epidemiological typing of Pseudomonas aeruginosa. In Resistance of Pseudomonas aeruginosa, edited by M. R. W. Brown, London, p. 189. 
CARney, S. A. AND Jones, R. J. 1968. Biological and immunochemical properties of culture filtrates of virulent and avirulent strains of Pseudomonas aeruginosa. Brit.J. exp. Path., 49, 395.

Doggett, R. G. AND Harrison, G. M. 1972. Pseudomonas aeruginosa: immune status in patients with cystic fibrosis. Infect. Immun. 6, 628.

Dubois, M., Gilles, K. A., Hamilton, J. K., Rebers, P. A. and Smith, F. 1956. Colorimetric method for determination of sugars and related substances. Analyt. Chem., 28, 350.

FELLER, I. 1966. The use of pseudomonas vaccine and hyperimmune plasma in the treatment of seriously burned patients. In Research in burns, edited by A. B. Wallace and W. A. Wilkinson, Edinburgh, p. 470.

Folch, J., Lees, M. ANd SlOANe-Stanley, C. H. 1957. A simple method for the isolation and purification of total lipides from animal tissues. J. biol. Chem., 226, 497.

Hanessian, S., Regan, W., WATsON, D. AND Haskell 1971. Isolation and characterisation of antigenic components of a new heptavalent pseudomonas vaccine. Nature (New Biol.), 229, 209.

HARTREe, E. F. 1972. Determination of protein: a modification of the Lowry method that gives a linear photometric response. Analyt. Biochem., 48, 422.

Hill, R. B., Dahrling, B. E., Starzl, T. E. AND Rifkind, D. 1967. Death after transplantation; an analysis of sixty cases. Am.J. Med., 42, 327.

Jones, R. J. 1968. Protection against Pseudomonas aeruginosa infection by immunisation with fractions of culture filtrates of Ps. aeruginosa. Br.J. exp. Path., 49, 411.

JoNEs, R. J. 1969. Immunogenic properties of culture filtrates of Pseudomonas aeruginosa. In Pharmacological treatment of burns, edited by A. Bertelli. (Excerpta Medica Int. Congress Ser. no. 190), p. 301.

JoNes, R. J. 1970. Passive immunisation against gram-negative bacilli in burns. Br. J. exp. Path., 51, 53.

JoNes, R. J. 1971. Early protection by vaccines in burns. Br.J. exp. Path., 52, 100.

JONES, R. J. 1972. Specificity of early protective responses induced by pseudomonas vaccines. J. Hyg., Camb., 70, 343.

Jones, R. J. 1975. Topical chemoprophylaxis against infection of burns. In Proc. Dutch Burns Ass., edited by R. Hermans, Beverwijk, Holland, p. 22.

Jones, R. J., Roe, E. A., Lowbury, E. J. L., Miler, J. M. AND Spilsbury, J. F. 1976. A new pseudomonas vaccine: Preliminary trial on human volunteers. J. Hyg., Camb., 76, 429.

LIEVE, L. 1968. Studies on the permeability change produced in coliform bacteria by ethylenediaminetetracetate. J. biol. Chem., 243, 2374.

Liu, P. V., ABe, Y and Bates, J. L. 1961. The roles of various fractions of Ps. aeruginosa in its pathogenesis. J. infect. Dis., 108, 218.

Lowbury, E. J. L. 1972. Infection associated with burns. Postgrad. med. J., 48, 338.

Lowbury, E. J. L. 1975. Ecological importance of Pseudomonas aeruginosa: medical aspects. In Genetics and biochemistry of Pseudomonas, edited by P. H. Clarke and M. H. Richmond, London, p. 37.

Lowbury, E. J. L. AND JoNEs, R. J. 1975. Treatment and prophylaxis for pseudomonas infections. In Resistance of Pseudomonas aeruginosa, edited by M. R. W. Brown, London, p. 237.

Miles, A. A., Misra, S. S. And Irwin, J. O. 1938. The estimation of the bactericidal power of blood. J. Hyg., Camb., 38, 732 .

Milner, K. C. AND Finkelstein, R. A. 1966. Bioassay of endotoxin: correlation between pyrogenicity for rabbits and lethality for chick embryos. J. infect. Dis., 116, 529.

VARLeY, H. 1962. Practical clinical biochemistry. 3rd ed. London, p. 148.

Zellner, P. R., Metzger, E. ANd Zwisler, O. 1975. Active immunization against Pseudomonas aeruginosa in burns. In Gram-negative bacterial infections, edited by $\mathbf{B}$. Urbaschek, R. Urbaschek, and E. Neter, Vienna and New York, p. 499. 